\title{
The management of AIDS in South African schools
}

\author{
Izak Oosthuizen \\ Faculty of Education \\ Potchefstroom University for CHE \\ POTCHEFSTROOM
}

\begin{abstract}
According to the Third National Survey conducted among women attending antenatal clinics in South Africa, 120,000 more people are estimated to have become infected with HIV since 1991 (Kustner, 1993a:34). Pupils and schools cannot be isolated from this serious health hazard in our country. In this article the relationship of confidentiality between a doctor and his patient is compared to the relationship between a pupil and a teacher. The question arises as to whether a teacher (i.c. the school principal) should be allowed to breach this confidence by revealing to the staff of his school the fact that a pupil is HIV-infected. Under certain circumstances the public interest in preserving human life outweighs the HIV-infected pupil's right to privacy.
\end{abstract}

\section{Introduction}

Van Wyk as quoted by Prinsloo and Beckmann (1993:51) emphasises the fact that AIDS is likely to become the most serious health hazard of this century. The pupils, parents and staff of our schools are not exempt from this problem. In accordance with the general function of law in of our society, the rights as well as the interests of the individual AIDS sufferer should be carefully weighed against the rights and interests of the school as a community (Prinsloo \& Beckmann, 1993:51). The situation becomes even more problematic when regarded in the light of the teacher's duty to take care of the physical (and mental) well-being of each pupil as an individual and the school community as a whole.

No case law exists as yet with regard to the management of the AIDS problem in South African schools. For this reason existing legislation and case law applicable to the medical practitioner will be analysed in an effort to find proper guidelines according to which the school principal (and the teacher) can manage this problem in our schools. 


\section{Problems relating to the education and prevention of AIDS in South Africa}

The school and its pupils and teachers cannot be isolated from the rest of society. For this reason, the trends within society that are relevant to AIDS are also of relevance to the school situation and should be taken into account in the management of AIDS at school.

\subsection{The continent of Africa}

Africa is deemed to be the continent which has been hardest hit by AIDS (Mann, 1988:60). According to figures released by the World Health Organisation, more than 600000 people in Zimbabwe (one of South Africa's neighbouring countries) have been infected by the HIV virus (SAPA, 1993:6). According to the same organisation, survey data showed that by 1992 HIV had spread throughout the country of Nigeria, averaging 22 percent in patients and nearly 6 percent in pregnant women (SAPA, 1993:6).

\subsection{AIDS in South Africa}

South Africa cannot be isolated from the rest of Africa, especially when the practice of migratory labour is taken into consideration. South African mining, for example, makes use of many migrant labourers from various parts of Africa. Being away from their own families for long periods of time, they often become involved in loose sexual relationships with local girl-friends and prostitutes (Moodie, 1988:228). Van der Walt adds to this the fact that long-distance drivers have contributed significantly to the spread of AIDS in Africa. He says that "prostitutes frequented the overnight facilities used by truck drivers" on the main routes (HSRC, 1993:1). In a survey almost 57\% of truck drivers admitted to making use of the services of prostitutes, very few making use of condoms (HSRC, 1993:1). This could of course contribute considerably to the local spread of AIDS

During the months of October and November of each year (since 1990) national surveys are conducted among women attending antenatal clinics throughout South Africa to determine the prevalence of the HIV epidemic in South Africa. The figures of the third South African National HIV survey which were released in May 1993, showed that a further 120,000 persons are estimated to have become infected with the HIV virus since 1991 (Kustner, 1993a:34). The estimated cumulative total now stands at 322,000 (out of a total population of 36 million) HIV-infections (Kustner, 1993a:34). (It was estimated in May 1987 that South Africa had a mere 6,000 to 7,000 carriers of the disease see - Strauss, 1988a:13.) 
One of the most alarming facts was the confirmation of the rapid growth of infection among the youth (Steinberg, 1992:2). The nationwide doubling time at present is 12 months (Kustner, 1993a:34).

\subsection{Confidentiality with regard to AIDS}

The National Progressive Primary Health Care Network (NPPHCN) finds it difficult to do its work regarding the prevention of AIDS in South Africa owing to the demand for confidentiality and the AIDS patient's right to privacy (Schaay, 1992:4). Whilst in some of the other African countries, such as Uganda and Zimbabwe, people are open about AIDS, a South African medical practitioner is expected to honour the privacy of a patient. This was also the viewpoint held by the court in the case of McGeary vs Kruger and Joubert in 1991 (Van Wyk, 1992:117) and confirmed by the subsequent decision by the Court of Appeal in Jansen van Vuuren and Another NNO v Kruger 1993(4) SA 842.

In research done by the Human Sciences Research Council (HSRC) a third of the respondents feared that a medical doctor would not respect the confidentiality of an AIDS patient (HSRC, 1993:1)

\subsection{Economic factors}

Various economic issues have an influence on the prevention of AIDS. Klugman, from the medical school of the University of the Witwatersrand, said that "AIDS is becoming a disease of the poor, of the less educated" (HSRC, 1993:2).

It is commonly accepted that a definite link exists between poverty and disease (Head, 1992:17). The relations between disease and overcrowded living conditions, a poor diet and inadequate housing is a proven medical fact. Many South Africans live in conditions of poverty where household income is hardly able to cover their basic food supply (Head, 1992:17). It is estimated that about 10 million people in South Africa (out of a total population of 36 million) fall into this category (SABC, 1993). One of the reasons for this is the high unemployment figure of an estimated 6 million people (SABC, 1993).

Among other things, poverty has an effect on people's ability to afford the recommended food, medicine and medical care.

The South African government was able to approve only R20 000000 (less than $\$ 6000000$ ) for AIDS programmes in 1992 (Stockton, 1992:5). Fortunately, various non-governmental organisations such as the NPPHCN, sponsored by private initiative, focus their activities on educational and preventative work in the area of AIDS. 


\subsection{Illiteracy}

An educational system disrupted by the political situation in South Africa has left many South African school students bereft of a reading culture so that they are not fully literate in English (Everett, 1992:8). This has a negative effect on their knowledge about AIDS.

\subsection{Attitudes towards sex education}

Everett (1992:9), a member of the South African Medical Research Council, reports that teachers are hesitant about supporting and promoting the Council's educational programmes as they feel that parents and colleagues might be offended. Research by the HSRC directed at establishing teachers' views on AIDS education showed that many teachers excluded all sections of the programme referring to sex, condoms and safe sex practices, as they felt that nothing should be taught which might be interpreted as condoning or encouraging pupils becoming sexually active (HSRC, 1993:2). Many Christian parents hold the view that small and immature children are confronted by issues such as condoms and sex which are issues that they are not yet mature enough to handle (Van der Walt, 1990:297). This viewpoint is supported by Christian churches in South Africa which believe that moral standards should rather be taken into consideration and that an unconditional openness about sex should be handled carefully (Stockton, 1992:6).

\subsection{Polygamous traditions}

Polygamy is a tradition of the black tribes of South Africa. Mokhobo (1988:34) says that this tradition continues today because of the fashion to have sexual contact with a great number of women. This practice has been confirmed by empirical research where the respondents thought that messages to 'stick to one partner' were ludicrous (HSRC, 1993:2).

\section{South African legal determinants for the management of AIDS}

\subsection{Common law}

South African common law with its unique indigenous character, was developed from Roman-Dutch and English law. A number of South African common law principles are relevant to the position of the teacher with regard to his conduct towards the HIV-infected pupil. For the purposes of this article the pupil's right to privacy and the in loco parentis position of the teacher will be emphasised. 


\subsubsection{Right to privacy}

The right to privacy is regarded by Neethling et al. (1990:294) as the right of an independent personality to an "individual condition of life characterised by isolation from the public and publicity". One of the ways in which this right to privacy can be infringed is by means of disclosure or revelation where an outsider acquaints (a) third party with the individual's personal affairs. One of the forms of violating an individual's right to privacy by means of disclosure is the divulging of private facts contradicting the right to confidentiality (Neethling et al., 1990:294). Similar to the well-known relationship of confidentiality which exists between a medical doctor and his patient is the relationship between a pupil and his teacher, which is also regarded as a relationship of confidence.

The basic common law principle in South Africa therefore determines that a teacher does not have the right to infringe a pupil's right to privacy. This basically boils down to the fact that he will be infringing a pupil's right of privacy if he informs a third party of the fact that the pupil is HIV-infected.

An outsider (i.c. teacher) will not be held liable for a deed of violation, however, if he can justify his act. Grounds for justification are described by Neethling $\boldsymbol{e t}$ al. (1990:61) as "special circumstances which reveal that conduct which appears to be wrongful is in reality lawful". The violation of the right to privacy of the HIV-infected pupil can be justified on the grounds of necessity. Necessity can be defined in terms of the defendant (i.e. a teacher) finding himself in such a position as a result of a superior compulsion allowing him to protect his own legal interests (and even that of another) by violating in a reasonable way the rights of an innocent third party (i.e. the AIDS-infected pupil and his right to privacy) (Neethling et al., 1990:61). Some of the conditions under which a defendant (i.e. the teacher) can claim necessity as grounds for justification are as follows (Neethling et al., 1990:74):

- The necessity must arise from a present situation or it must be imminent.

- Interests such as property and privacy (i.e. the right to privacy of the AIDSinfected pupil) may be protected. In the court case of the State vs Goliath 19723 SA (A) it was held that even homicide may be justified under certain conditions.

- The general principle is that the interest sacrificed should not be more valuable than the interest which is protected.

- The defendant (i.e. the teacher) need not only protect his own interests but he is also entitled to protect the interests of others (such as children). 


\subsubsection{The in loco parentis-position of the teacher}

The South African teacher's position as a person in loco parentis is based on common law. Literally translated, it means 'to stand in the place of the parent'. Although the teacher can never replace the parent as the primary educator of the child, he acts on behalf of the parent in the physical absence of the parent during school activities. His role as person in loco parentis requires the teacher to take disciplinary control of the pupil and to undertake diligent supervision of the pupil. The diligent supervision includes protecting the physical as well as the mental well-being of the pupil. Teachers who have been found negligent in their obligation of diligent supervision towards an individual pupil or the pupils as a group have been held liable for damage on various occasions in the past (Bray et al., 1989:96).

Not only does the teacher have a responsibility towards the physical well-being of the HIV-infected pupil, but also towards the rest of the pupils at school. A teacher could be held liable for the infection of pupils in a case where, knowing that a certain pupil is HIV-infected, he allows him to participate in a contact sport such as rugby football, thereby endangering the safety of other pupils. The position would apply even if the teacher is not personally in control of the specific activity, but where he has knowledge of the fact that the infected pupil is participating in the said activity which falls under the control of a colleague. This is especially the case with regard to the position of the school principal. Here the teacher needs to weigh up the interest sacrificed (the individual HIV-infected pupil's right to privacy) against the right of the other pupils at school to supervision and physical safety (see the discussion on necessity in a previous paragraph). The general principle is that the interest which is sacrificed should not be more valuable than the interest which is protected.

\subsection{Legislation}

Regulations relating to transmissible diseases promulgated in terms of the Health Act (Act 63 of 1977) classify AIDS as a non-notifiable disease. According to health regulations published in the Government Gazette of 30 October 1987 a school principal who is aware of or suspects a pupil (or a staff member) of being HIV-infected must immediately inform the medical officer of health (or the administrative head) of the local authority about the situation (Strauss, 1988b:5).

Legislation on education is promulgated at different levels ranging from parliamentary legislation to second and third level of subordinate legislation. 


\subsubsection{Parliamentary legislation}

\subsubsection{The Educational Affairs Act (House of Assembly) (Act 70 of 1988)}

According to Section 53 of this Act a child is compelled to attend school from the first day of the year in which he turns 7 years of age up to the last day of the year in which he turns 16 years of age. According to Section 54 of the Act a child can, however, be exempted from compulsory school attendance by the Head of Education (for such a period and under such conditions as he may determine) where the pupil, as a result of continuous ill-health, is not able to attend school (This obviously includes the AIDS-infected pupil who, as a result of continuous ill-health, is not able to attend school.)

\subsubsection{Regulations promulgated in terms of the Educational Affairs Act (House of Assembly)}

These Regulations were promulgated by the Minister of Education and Culture (House of Assembly). The Regulations relating to Medical, Psychological and Dental Examinations of Pupils at Public Schools specify that where a school principal is of the opinion that the mental and physical condition of a child requires a medical, psychological or dental examination, he may order such an examination by a person authorised by the Director of Education to do so. It is the duty of a parent to enforce a pupil to undergo such an examination. The Department of Education and Training has similar provisions with the exception that the authority to order medical examinations is vested in the person of the Director of Education of the Department (Regulations regarding the rendering of Health Services in Schools; Regulations published under the Education and Training Act of 1979.)

\subsubsection{Departmental provisions}

An education department holds delegated authority which enables it to issue provisions which are in line with the applicable educational Acts and Regulations. An example of such a departmental provision is the Manual for General School Organisation of the Transvaal Education Department (TED, 1993). A comprehensive outline dealing with the management of pupils infected with AIDS forms part of this Manual (TED, 1993:9):

As AIDS cannot be transmitted through casual contact it is important that HIV-carriers and AIDS-sufferers should not be excluded from education institutions unless they 
* are neurologically handicapped and have no control over the excretion of body fluids;

* display deviant behaviour such as biting other pupils or using intravenous drugs;

* have skin diseases which result in open sores which cannot be bandaged; or

* are sexually active.

Alternative education should be provided for those carriers who, for the reasons given above or owing to rejection, cannot be accommodated in a particular institution.

It is important that each case should be dealt with individually. The behaviour and general state of health of all carriers should be monitored regularly as these factors will determine whether they may continue their schooling at a particular institution in the case of their condition stabilizing, or whether they should receive alternative education.

Carriers will therefore have to be placed under continuous medical supervision and medical officers will have to evaluate the ability of the institution concerned to provide the care required. If the risk is too high, the carrier should receive alternative education

To divulge medical information concerning a patient to a third party without the consent of the patient or the patient's parents/guardians (in instances where the patient is a minor) is illegal and unethical and shows a total disregard for a patient's right to privacy.

In dealing with AIDS sufferers, the following guidelines are to be followed (TED, 1993:10):

(i) The underlying principle in dealing with an HIV carrier or AIDS sufferer is to protect the staff, pupils and the general public whilst at the same time respecting the rights of the individual to privacy and confidentiality, provided that the broad interests of the community concerned are not compromised.

(ii) All institutions are to pay particular attention to the following aspects irrespective of whether or not they have HIV carriers or an AIDS sufferer at the institution

* Staff, pupils and parents should be well-informed about the disease. The preconceptions and fears of members of staff should be allayed. 
* Teaching staff should be sensitive to the general state of health of all pupils at all times. Principals should be informed of problematic cases and should deal with these cases discreetly.

* Institutions are to implement routine procedures when dealing with blood or body fluids and these should be strictly adhered to irrespective of whether or not there are carriers at the institution.

- Gloves must be used where there is any contact with blood or excretions and they should be destroyed once they have been used

- Gloves and dressings should be sealed in plastic bags and destroyed immediately after use.

- Open wounds, sores and grazes should be bandaged.

- Hands exposed to contact with blood or body fluids should be washed

- Surfaces which may be infected are to be cleaned and disinfected with a chlorine solvent.

* Pupils are to receive family guidance and health education which deal explicitly with the AIDS problem. They should also be well-informed on the dangers of drug abuse.

* General hygienic procedures should be instituted and brought to the attention of both staff and pupils as these measures will protect everyone involved not only against AIDS but also against other infections.

* Should any pupil sustain an open wound in a contact sport, the referee/supervisor is to stop play and order the pupil off the field until such time as the bleeding has been stopped and the wound has been disinfected and properly bandaged.

\subsubsection{Quasi legislation}

Baxter (1984:200) describes quasi or impure legislation as a body of rules which exists between law and administrative practice and which is of great relevance to the exercising of discretionary administrative powers. The various ethical codes for South African professions such as the medical profession, teaching, etc. are examples of quasi legislation.

Ethical guidelines for the medical profession regarding the handling of an AIDSinfected patient are quoted by Van Wyk (1992:120, 12I): 
The health care professions are fully aware of the general rules governing confidentiality.

Council is confident that if doctors fully discuss with patients the need for other health care professionals to know of their conditions in order to offer them optimal treatment and also to take precautions when dealing with them, the reasonable person of sound mind, will not withhold his consent regarding divulgence to other health care workers.

If, having considered the matter carefully in the light of such counselling, the patient still refuses to have other health care workers informed, the patient should be told that the doctor is duty bound to divulge this information to the other health care workers concerned with the patient. All persons receiving such information must of course consider themselves under the same general obligation of confidentiality as the doctor principally responsible for the patient's care.

If it were found that an act or omission on the part of a medical practitioner or dentist had lead (sic) to the unnecessary exposure to HIV infection of another health care worker, the Council would see this in a very serious light and would consider disciplinary action against the practitioner concerned.

Although these are only (advisory) guidelines, and therefore not a binding ethical code for medical practitioners, they serve as a very definite indication of the attitude of the South African medical profession as to what is to be regarded as a model for the reasonable behaviour of the medical practitioner.

\subsection{Case law}

Van Wyk (1992:116) regards the unreported case of McGeary vs Kruger and Joubert (1991-10-16, case no. 25317/90 (W)) as the locus classicus regarding the AIDS sufferer's right to privacy. In this case McGeary, the applicant (an HIV-infected patient of the respondent) claimed damages from his medical doctor (Kruger) for breaching his right to privacy by informing the local dentist as well as another practitioner of McGeary's condition while they were playing golf. The decision of the court made it clear that medical workers have the right to breach a HIV-infected patient's right to privacy by informing another health care worker of the patient's condition if it is likely that such a health care worker might get involved in the treatment of that patient. The judge came to the conclusion that "in the light of the major threat posed by AIDS to society internationally ... its victims ... may have their right to privacy affected in the interests of society. It is considered that the latter interests outweigh the individual's right to privacy" (Van Wyk, 1992:118). He further noted that the seriousness of the disease demands a "generous approach to the need for health care workers to be kept fully 
informed and to subordinate the interests of the patient to that need" (Van Wyk, 1992:118). In the subsequent Court of Appeal decision (Jansen van Vuuren and Another NNO v Kruger 1993(4) SA 842), this decision was reversed. In this case the judge confirmed that "a doctor could be justified in disclosing his knowledge where his obligations to society were of greater weight than his obligations to the individual". He continued to say that in determining whether a medical doctor was justified in violating his obligation of privacy towards a patient for the sake of social interests, the standard of the reasonable man is to be applied. He held that in this particular situation the medical doctor's violation of the patient's right to privacy was unreasonable since he expressly undertook not to divulge the patient's status.

\section{Possible solutions for the management of AIDS}

\subsection{Attack on poverty}

Even although it is not a priority of the school to fight poverty in South Africa, the breaking down of poverty will have an influence on AIDS in the macro society of which the school community forms an integral part.

An attack on the conditions of poverty should become an urgent priority. Recently the South African government started making funds available for the community development of poverty-stricken communities. Apart from this, much private initiative (such as the Ithuba project, the Independent Development Trust, the Southern African Development Bank, the Urban Foundation, the Rural Foundation, the D.G. Murray Trust) is raising and channelling money towards these communities.

\subsection{Educational guidelines for the management of AIDS at school}

As far as the management of AIDS within the school is concerned, there are a few legal, managerial and educational considerations which could be regarded as possible solutions to the management of the problem in our schools.

\subsubsection{Restraint}

The first aspect about AIDS which pupils should learn is that of sexual restraint. Biblical guidelines such as sexual restraint should be re-emphasized among the young. These will not be of any use, however, if the correct example is not set by adults. The culture of immorality holds sway over South Africa (and Western society) and must be substituted by Biblical values. 


\subsubsection{The education of pupils}

Education and training are essential components of the effort to prevent the transmission of the HIV virus. According to Heyns (1992:5) all other measures instituted to prevent the transmission of this disease will "probably fail if they are not supported by an ongoing educational programme".

Dr. Kustner (1993b:1) of the Department of National Health and Population Development said that by the year 2000 the number of HIV infections in South Africa will stand at about 4 million persons of which young South Africans will form the majority. He also emphasised the fact that young South Africans are to be the key target audiences in the AIDS education process since they are the future and form the group most susceptible to infection resulting from ignorance and unsafe sex practices.

An educational programme should be instituted where pupils are informed about the dangers of AIDS, the ways in which it is transmitted and how one should go about preventing infection. In the United States certain aspects of the AIDS educational programme (such as the use of condoms) are voluntary (Zirkel, 1992:347). As the views of all South African parents and Christian churches should be respected, an educational programme based on voluntary (and with the consent of the parent) attendance by pupils (and their parents) could be considered. The programme should be run after school hours to enable parents to attend it. In this way the parents can develop confidence in this kind of programme. It will also assist those parents who have an open relationship with their children regarding sexual issues, to extend this to the issue of AIDS, and to answer their children's questions (which they might have been too shy to ask in front of the group during an educational session). Once parents' support for the contents, respectability and aims of such a programme has been obtained, it will give momentum to the success of the programme. A programme such as this has been developed and presented by the Transvaal Education Department since 1990. According to Louw (1994) this family guidance programme proved to be a big success in the school district of Pretoria. This was confirmed by Cory (1994) concerning the success of the programme in Potchefstroom.

In 1992 the South African Medical Research Council's AIDS Research Programme initiated a unique programme when they developed an AIDS educational comic (Everett, 1992:8). The aim of the comic is "to influence prevailing youth culture so it becomes more supportive of behaviour that prevents HIV transmission" (Everett, 1992:8). The comic as a medium has proved popular and familiar among South African teenagers and should therefore be a very successful means of practising AIDS education. Not only was this comic translated into the indige- 
nous languages of Zulu and Sotho, but it is also being translated into Xhosa and Afrikaans.

\subsubsection{Securing the position of the teacher}

A medical doctor stands in a relationship of confidentiality with his patients. The right of a medical doctor to breach this confidence by warning third parties who are at risk of suffering harm from his patient, is not entrenched by legislation in South Africa. The court case of McGeary vs Kruger and Joubert in 1991 (Van Wyk, 1992:117) held that a doctor has the right to reveal to a medical colleague that a patient is HIV-infected.

Principles of Medical Ethics of the American Medical Association are clear about this (Burchell, 1990:256):

A physician may not reveal the confidences entrusted to him in the course of medical attendance ... unless he is required to do so by law or unless it becomes necessary in order to protect the welfare of the individual or the community.

Beckmann and Prinsloo (1993:54) state emphatically that "the overriding social interest will justify the unauthorised disclosure of confidential facts. In some instances, a doctor may even have a duty to inform".

The position of the teacher, and especially that of the school principal, should be regarded as similar in many instances:

- Between the teacher and the pupils of his school a relationship of trust and confidence exists. "Education is basically built on a relationship of trust" (Bondesio, 1989:38), which implies that a special effort should be made to protect the interests of the child. Bondesio (1989:38) also adds that special care should be taken in order to ensure that the interests of the child are protected by not using sensitive information about the child to his disadvantage or to break the relationship of trust between the child and the teacher.

- As a result of his in loco parentis position the teacher is responsible for the physical safety and well-being of all the pupils of his school.

As possible answer to the question asked by Beckmann and Prinsloo (1993:54) as to 'who will be liable?' if the principal does not inform the teachers, pupils and other persons at school of the conditions of the AIDS sufferer and someone does get infected, could be found within the legal guidelines which are applicable to the medical doctor. As mentioned in paragraph 3.2.19(d) the guidelines for the reasonable man (i.c. medical doctor) is to inform other health care professionals of the condition of the infected patient in order to offer optimal treatment and care 
and also to take the necessary precautions in dealing with the patient. A medical practitioner's omission to inform another health care worker which leads to the unnecessary exposure to, and infection by the HIV virus, would be regarded by the Medical Council in a very serious light, and could even "lead to disciplinary action against the practitioner concerned" (Van Wyk, 1992:121).

Likewise, if the principal's (or a teacher's) omission to inform other staff members about the condition of the HIV-infected pupil leads to their (the staff's) unnecessary exposure and infection, he could well be held liable. To enable the teacher to perform these obligations, it is clear that he should be in the same position as the medical doctor whereby he should have the right to inform the staff concerned about the condition of AIDS-infected pupils. As in the case of the medical doctor, this is a situation where the public interest at school outweighs the individual pupil's right to privacy. The teaching staff receiving this information should, however, be under the obligation of confidentiality in order to secure the pupil's right to privacy. This viewpoint is confirmed by one of the most recent circulars (13 August 1993) of the Orange Free State Department of Education: if after explaining to the pupil and his parent the importance of revealing the condition of the HIV-infected pupil to the school staff, the parent still refuses the principal permission to do so, "the principal could as a last resort inform the staff without the permission of the person or the parent ..." (OFS Department of Education, 1993:5).

Apart from the right that a principal has to inform his teachers about the condition of the HIV-infected pupil, a teacher should also have the right to inform the principal to enable the principal to manage the situation.

\subsubsection{Legislation}

Where educational legislation is at present being promulgated to bring about a unified educational system in the form of one department it would serve a good purpose if the various stipulations of the existing legislation were consolidated. In doing so, the provisions of the Act and the accompanying Regulations of the Educational Affairs Act (House of Assembly) should be adopted because:

- The applicable provisions of this Act are far more detailed than those of the other Acts.

- It decentralises departmental powers by entrusting medical examinations to the man on the spot - the school principal.

Detailed departmental provisions for the management of the AIDS problem at school should be made. A workable model for this is contained in the existing specifications regarding the management of AIDS in the Manual for General School Organisation drawn up by the Transvaal Education Department. 


\section{Conclusion}

In the light of the many prevailing uncertainties regarding the rights, duties and the protection of pupils as well as teachers who are confronted with AIDS in our schools (Beckmann \& Prinsloo, 1993:51), more specific clarity should be brought about by legislators for the management of the AIDS problem in our schools.

\section{Bibliography}

BAXTER, L. 1984. Administrative Law. Johannesburg : Juta.

BECKMANN, J.L \& PRINSLOO, J.G. 1993. Some Legal Aspects of AIDS in Schools and Other Educational Institutions. South African Journal of Education, 13(2):51.

BONDESIO, M.J. 1989. The Teacher and the Pupil (In Bondesio, M.J., Beckmann, J.L., Oosthuizen, I.J., Prinsloo, J.G \& Van Wyk, J.G. The Teaching Profession: Legal Requirements Pretoria : J.P. van der Walt. p. 17-46.)

BURCHELL, J. 1990. The Legal Position of the AIDS Sufferer. Businessman's Law', 19(8) 255-258

BRAY, W., VAN WYK, J.G. \& OOSTHUIZEN, I.J. 1989. Case Law on Education. Durban : Butterworths.

CORY, H. (Deputy Superintendent of Education: Family Guidance.) 1994. Oral information to author. Potchefstroom

EVERETT, K. 1992. The Development of an AIDS Photo-Comic for South African Teenagers. AIDS Bulletin, 1(2):7-9

HEAD, J. 1992. Behavioural Assumptions about the Spread of HIV Infection in South Africa. AIDS Bulletin, 1(2):16-19.

HEYNS, A. DU P. 1992. Ethical Considerations and Recommendations in the Management of Patients with the HIV Infection or AIDS. SAMC Guidelines, 920804

HSRC

see

HUMAN SCIENCES RESEARCH COUNCIL

HUMAN SCIENCES RESEARCH COUNCIL. 1993. AIDS Poor Most at Risk. CSD Bullein. Pretoria : Human Sciences Research Council.

KUSTNER, H.G.V. 1993a. Editorial. Epidemiological Comments, 20(3). Pretoria : Department of National Health and Population Development

KUSTNER, H.G.V. 1993b. Press release on 14 May 1993. Pretoria : Department of National Health and Population Development

LOUW, C. (Deputy Superintendent of Education: Family Guidance.) 1994. Oral information to author. Pretoria

MANN, J.M. 1988. The International Epidemiology of AIDS. Scientific American, 259(4) 63.

MOKHOBO, D 1988. Sexual Attitudes amongst Black Youths with Special Reference to AIDS. AIDS proceedings: selected papers and task group reports of the AIDS congress Strategies for Southern Africa, 88. Johannesburg

MOODIE, T.D. 1988. Migrancy and Male Sexuality on the South African Gold Mines. Journal of Southern African Siudies, 14(2):28.

NEETHLING, J., POTGIETER, J.M., \& VISSER, P.J. 1990. Law of Delict. Durban : Butterworths 
The management of Aids in South African schools

ORANGE FREE STATE DEPARTMENT OF EDUCATION. 1993. Circular: Guidelines for Dealing with Persons with the HIV and AIDS, and the Prevention of HIV Infection (o. 16/1/4/2/19). Bloemfontein.

SABC

see

SOUTH AFRICAN BROADCASTING CORPORATION

SAPA. 1993. Zimbabwe Aids Toll Now 600,000. The Star, 9 June 1993.

SCHAAY, N. 1992. The Aids Programme of National Progressive Primary Health Care Network. AIDS Bulletin, 1(2): 1

SOUTH AFRICAN BROADCASTING CORPORATION. 11 August 1993. Agenda. Johannesburg.

REPUBLIC OF SOUTH AFRICA. Regulations Published under the Education and Training Act (Act 90 of 1979). Pretoria : Government Printers

REPUBLIC OF SOUTH AFRICA. Educational Affairs Act (House of Assembly) (Act 70 of 1988). Pretoria : Government Printers

STOCKTON, N. 1992. Striving for a Community-Driven National Programme. AIDS Bulletin, 1(2):5-7.

STEINBERG, M. 1992. Demographics of AIDS. Press conference held on 14 May 1993 Pretoria : Medical Research Council.

STRAUSS, S.A. 1988a Legal Issues Concerning AIDS South African Practice Management, $9(1): 13-14$.

STRAUSS, S.A. 1988b. Oordraagbare siektes en aanmelding van aanmeldbare mediese toestande. South African Practice Management, 9(4):5

TED

see

TRANSVAAL EDUCATION DEPARTMENT

TRANSVAAL EDUCATION DEPARTMENT (TED). 1993. Manual for General School Organisation. TED : Pretoria

VAN WYK, C.J. 1992. Vonnisse. Tydskrif vir Hedendaagse Romeins-Hollandse Reg, 55(1):116-124

VAN DER WALT, M. 1990. Die immunologie van HIV. Koers, 55(3):297-315.

ZIRKEL, P.A. 1992. A Case of Condoms. Phi Delta Kappan, 74(4):347-348. 